\title{
Alkali resistivity of $\mathrm{Cu}$ based selective catalytic reduction catalysts Potassium chloride aerosol exposure and activity measurements

\author{
Putluru, Siva Sankar Reddy; Jensen, Anker Degn; Riisager, Anders; Fehrmann, Rasmus
}

Published in:

Catalysis Communications

Link to article, DOI:

10.1016/j.catcom.2011.11.014

Publication date:

2012

Link back to DTU Orbit

Citation (APA):

Putluru, S. S. R., Jensen, A. D., Riisager, A., \& Fehrmann, R. (2012). Alkali resistivity of Cu based selective catalytic reduction catalysts: Potassium chloride aerosol exposure and activity measurements. Catalysis Communications, 18, 41-46. https://doi.org/10.1016/j.catcom.2011.11.014

\section{General rights}

Copyright and moral rights for the publications made accessible in the public portal are retained by the authors and/or other copyright owners and it is a condition of accessing publications that users recognise and abide by the legal requirements associated with these rights.

- Users may download and print one copy of any publication from the public portal for the purpose of private study or research.

- You may not further distribute the material or use it for any profit-making activity or commercial gain

- You may freely distribute the URL identifying the publication in the public portal 


\title{
Alkali resistivity of $\mathrm{Cu}$ based selective catalytic reduction catalysts: Potassium chloride aerosol exposure and activity measurements
}

Siva Sankar Reddy Putluru ${ }^{1,2}$, Anker Degn Jensen ${ }^{1}$, Anders Riisager ${ }^{2}$ and Rasmus Fehrmann ${ }^{* 2}$. ${ }^{1}$ Combustion and Harmful Emission Control Research Centre, Department of Chemical and Biochemical Engineering, Building 229, Technical University of Denmark, DK-2800 Kgs. Lyngby,

Denmark

${ }^{2}$ Centre for Catalysis and Sustainable Chemistry, Department of Chemistry, Building 207, Technical University of Denmark, DK-2800 Kgs. Lyngby, Denmark

\begin{abstract}
The deactivation of $\mathrm{V}_{2} \mathrm{O}_{5}-\mathrm{WO}_{3}-\mathrm{TiO}_{2}, \mathrm{Cu}-\mathrm{HZSM} 5$ and $\mathrm{Cu}-\mathrm{HMOR}$ plate type monolithic catalysts was investigated when exposed to $\mathrm{KCl}$ aerosols in a bench-scale reactor. Fresh and exposed catalysts were characterized by selective catalytic reduction (SCR) activity measurements, scanning electon microscope- energy dispersive X-ray spectroscopy (SEM-EDX) and $\mathrm{NH}_{3}$-temperature programmed desorption ( $\left.\mathrm{NH}_{3}-\mathrm{TPD}\right) .95 \%$ deactivation was observed for the $\mathrm{V}_{2} \mathrm{O}_{5}-\mathrm{WO}_{3}-\mathrm{TiO}_{2}$ catalyst, while the $\mathrm{Cu}-$ HZSM5 and Cu-HMOR catalysts deactivated of only $58 \%$ and $48 \%$, respectively, after $1200 \mathrm{~h} \mathrm{KCl}$ exposure. SEM analysis of the $\mathrm{KCl}$ aerosol exposed catalysts revealed that the potassium salt not only deposited on the catalyst surface, but also penetrated into the catalyst wall. Thus, the $\mathrm{K} / \mathrm{M}$ ratio $(\mathrm{M}=\mathrm{V}$ or $\mathrm{Cu}$ ) was high on $\mathrm{V}_{2} \mathrm{O}_{5}-\mathrm{WO}_{3}-\mathrm{TiO}_{2}$ catalyst and comparatively less on $\mathrm{Cu}-\mathrm{HZSM} 5$ and $\mathrm{Cu}-\mathrm{HMOR}$ catalysts. $\mathrm{NH}_{3}$-TPD revealed that the $\mathrm{KCl}$ exposed $\mathrm{Cu}-\mathrm{HZSM} 5$ and $\mathrm{Cu}-\mathrm{HMOR}$ catalysts only experienced a slight loss of acidity while the $\mathrm{V}_{2} \mathrm{O}_{5}-\mathrm{WO}_{3}-\mathrm{TiO}_{2}$ catalyst lost most of the acidity. High alkali resistivity seems to be characteristic of the zeolite supported SCR catalysts which thus could be attractive for flue gas cleaning in biomass plants.
\end{abstract}

Keywords: $\mathrm{SCR}$ of $\mathrm{NO}$ with $\mathrm{NH}_{3}$; Cu-zeolite catalysts; Biomass fired power plants

* Corresponding author. Tel.: +45 45252389; fax: +45 45883136; E-mail address: rf@ kemi.dtu.dk 


\section{Introduction}

The selective catalytic reduction (SCR) of nitrogen oxides $\left(\mathrm{NO}_{\mathrm{x}}\right)$ with $\mathrm{NH}_{3}$ as the reducing agent has been recognised as the most effective method for removal of $\mathrm{NO}_{\mathrm{x}}$ from stationary sources of energy by combustion of fossil fuels [1-4]. The catalyst consists of $\mathrm{V}_{2} \mathrm{O}_{5}$ dispersed on the surface of a $\mathrm{TiO}_{2}$ carrier. In order to enhance activity and robustness of the catalyst other metal oxides are added as promoters, mostly $\mathrm{WO}_{3}$ or $\mathrm{MoO}_{3}$. The $\mathrm{NH}_{3}-\mathrm{SCR}$ process is furthermore considered to have the highest potential to meet strict diesel emission standards in mobile applications $[5,6]$.

In principle a SCR catalyst should be durable, since it is not consumed during the reaction. This is unfortunately not the case, since it deactivates over time. Catalyst deactivation can be categorized in two types: physical and chemical deactivation. Physical deactivation occurs when the pores or channels in the catalyst structure clogs, resulting in a diminishing of the surface area and the number of accessible active surface sites. This can be caused either by dust in the off-gas or by deposition of salts formed during the combustion. Chemical deactivation occurs when a compound reacts with an active site, and by here makes the site catalytically inactive.

Biomass includes organic matter like trees, agricultural crop and timber waste, aquatic plants, animal waste, municipal and industrial waste. Contrary to fossil fuels they are regarded as environmentally sustainable energy sources, since they are part of the carbon eco-cycle on earth and thus an energy source with zero- or at least "low" $\mathrm{CO}_{2}$ footprint. Combustion of natural gas and fossil fuels such as coal leads to a relatively clean flue gas, whereas combustion of, e.g. municipal waste or biomass, often contain species that can lead to deactivation of the traditional vanadiatitania-based SCR catalyst [7-17]. Biomass combustion result in formation of particulates with high concentration in the submicrometer range. The flue gas particles are formed via condensation, 
nucleation, and chemical surface reactions of inorganic compound vapours when the gases are cooled downstream the boiler $[8,9]$.

The deactivation of SCR catalysts under biomass combustion has been ascribed to the potassium presence of submicrometer particles which can poison the catalyst active sites or mask them through pore fouling [7]. The element composition of various fuels and ash formed in industrial biomass fired power plants, have recently been reported [8-11]. Studies show a significant increase in the quantity of alkali and alkaline-earth elements ( $\mathrm{K}, \mathrm{Na}, \mathrm{Mg}, \mathrm{Ca}$ ), phosphorous and chlorine in the flue gas produced from biomass-based fuels compared to coal [9]. The content of potassium and chlorine in straw can be more than an order of magnitude higher than in coal. Especially the high content of potassium in e.g. wood and straw, is of concern. Alkali metals were identified early as poisons for vanadia-titania based SCR catalysts by Chen and Yang [10]. They found that the strength of the poison is related to the increase in basicity of the alkali salt. Potassium salts are thus considered a stronger poison to the vanadium-based catalyst than sodium and lithium salts.

Chemical deactivation of catalysts by deposition of alkali poisons have been investigated with different methods, such as wet-chemical impregnation [5, 10-12], aerosol exposure [13] and flue gas exposure in power plants $[8,14]$. Usually the wet-chemical impregnation method is preferred to screen the catalysts, since it is fast and allows the poison level of deactivation to be controlled by the amount of poison added. However, compared to lab scale wet-chemical impregnation, potassium aerosol exposure and flue gas exposure in power plants are considered as more realistic test methods.

Moradi et al. [15] found that aerosol deposition on the catalyst surface can slow down the reagent species diffusion and thereby decrease the reaction activity. Moreover, the authors reported that inorganic submicrometer particle penetration in the pore structure depends on the nature of the 
species. Alkali aerosols can not only deposit on the catalyst surface but also reach the inner parts of the monolith wall due to their high diffusion coefficient. It is reported that $\mathrm{K} / \mathrm{V}$ molar ratio of 0.3 is enough to completely poison the catalyst $[13,14]$. Additionally, it was reported that the observed rate of deactivation is so high that use of SCR in purely straw-fired power plants seems impractical with the present industrial $\mathrm{V}_{2} \mathrm{O}_{5}-\mathrm{WO}_{3}-\mathrm{TiO}_{2}$ catalyst.

Potential alternatives to the vanadium-based SCR systems are supported $\mathrm{Fe}$ and $\mathrm{Cu}$ oxide catalysts $[4,6,11]$. Ideally, the support should be thermally stable, have high surface area and be strongly acidic in order to attract alkali metals and thus protect the active metal sites for alkali poisoning. In our previous studies, we reported alkali resistivity of $\mathrm{Cu}$ /zeolite and $\mathrm{V}_{2} \mathrm{O}_{5} / \mathrm{zeolite}$ deNOx catalysts for flue gas cleaning in biomass fired applications with wet-chemical impregnation by potassium nitrate $[11,16]$. A recent report on the effect of inorganic additives on Fe-zeolite catalysts showed improved poisoning resistivity compared to the industrial $\mathrm{V}_{2} \mathrm{O}_{5}-\mathrm{WO}_{3}-\mathrm{TiO}_{2}$ catalyst [6]. Currently there is no commercial catalyst available for deNOx in flue gas from biomass units. Thus it seems interesting to test zeolite based catalysts under more realistic aerosol conditions and compare with industrial $\mathrm{V}_{2} \mathrm{O}_{5}-\mathrm{WO}_{3}-\mathrm{TiO}_{2}$ catalysts.

In this work, HZSM5 and HMOR reinforced plate type catalysts are prepared by dipcoating of the glass fiber support and subsequently impregnation by a copper nitrate solution [11]. The resulting $\mathrm{Cu}-\mathrm{HZSM} 5$ and $\mathrm{Cu}-\mathrm{HMOR}$ catalysts were deactivated along with a $\mathrm{V}_{2} \mathrm{O}_{5}-\mathrm{WO}_{3}-\mathrm{TiO}_{2}$ (VWT) catalyst by exposure to $\mathrm{KCl}$ aerosols in a bench-scale reactor for $1200 \mathrm{~h}$. The SCR activities of the fresh and deactivated catalysts are compared and discussed based on characterization methods. For the actual application in the power plants the catalyst should have monolithic shape and deactivation measurements of those are necessary under realistic conditions unlike fast wet impregnation poisoning of particles [16]. 


\section{Experimental}

\section{1 $\mathrm{Cu} /$ zeolite plate type monolith catalyst preparation}

Two glass fiber plate type monoliths (Haldor Topsøe A/S, Denmark) were used as substrates for dip coating. The fiber material consists primarily of $\mathrm{SiO}_{2}$ but also alumina and calcium to a lesser extent. The catalysts were prepared by immersing the glass fiber plate into a zeolite suspension. Two different types of zeolites (Zeolyst International) H-Mordenite ( $\mathrm{Si} / \mathrm{Al}=10$ and $\left.400 \mathrm{~m}^{2} / \mathrm{g}\right)$ and $\mathrm{H}-\mathrm{ZSM} 5\left(\mathrm{Si} / \mathrm{Al}=15\right.$ and $\left.500 \mathrm{~m}^{2} / \mathrm{g}\right)$ were used. The suspension was prepared by mixing 20 wt.\% zeolite and 5 wt.\% colloidal silica (LUDOX ${ }^{\circledR} \mathrm{HS}$ - 30, particle diameter 20-24 nm, Aldrich) with demineralized water in a wet fluid mill until a stable uniform slurry was formed. The fiber plates were immersed in the suspension for $3 \mathrm{~min}$ each, and excess suspension was removed by air blowing. To obtain better reinforcement of zeolite on the glass fiber plate the average particle size of the suspension should be $<5 \mu \mathrm{m}$. The zeolite reinforced plates were dried at $120^{\circ} \mathrm{C}$ for $8 \mathrm{~h}$ and weighed to find the gain in weight. $4 \mathrm{wt} . \% \mathrm{Cu}$-zeolite catalysts were then prepared by incipient wetness impregnation of the zeolite plates using appropriate amounts of copper nitrate (Aldrich, 99.99\%) solutions as precursor. The samples were finally calcined at $500^{\circ} \mathrm{C}$ for $4 \mathrm{~h}$ at a heating rate of $2^{\circ} \mathrm{C} / \mathrm{min}$. A commercial $\mathrm{V}_{2} \mathrm{O}_{5}-\mathrm{WO}_{3}-\mathrm{TiO}_{2}$ plate type catalyst (VWT) was used for comparison. The catalyst plate contained $3 \mathrm{wt} . \% \mathrm{~V}_{2} \mathrm{O}_{5}$ and about $7 \mathrm{wt} . \% \mathrm{WO}_{3}$ on a fiber reinforced $\mathrm{TiO}_{2}$ carrier. The plates had dimensions of $50 \mathrm{~mm}$ x $160 \mathrm{~mm}$ x $1.3 \mathrm{~mm}$ and were cut into $40 \mathrm{~mm} \times 120 \mathrm{~mm}$ x 1.3 $\mathrm{mm}$ for the exposure.

The particle size of the supplied zeolites was decreased using 3-5 mm glass beads in a wet fluid mill. The milling was continued untill the average particle size was reduced to about $2-4$ $\mu \mathrm{m}$. The particle sizes of the supplied powders and the milled powders were determined by the laser beam scattering technique using a Malvern Mastersizer 2000 particle size analyzer (Malvern 
Instruments Ltd., Worcestershire, U.K.) equipped with a sample suspension unit and an ultrasonicator. Obscurations in the range of $10-20 \%$ were used during the measurement.

\subsection{KCl aerosol exposure}

To expose the two $\mathrm{Cu}$ /zeolite catalysts (one $\mathrm{Cu}-\mathrm{HMOR}$ and one $\mathrm{Cu}-\mathrm{HZSM}$ ) to alkali poisons under realistic power plant conditions the plate type catalysts were placed in the pilot plant reactor shown in Fig. 1 and exposed to well-defined aerosols of $\mathrm{KCl}$. For comparison one commercial vanadium catalyst (VWT) was also exposed. Hot flue gas was produced by a $50 \mathrm{~kW}$ natural gas burner and a solution of the salt in distilled water $(7.4 \mathrm{~g} / \mathrm{l} \mathrm{KCl})$ (Aldrich, 98\%) was prepared and mixed before being added to the system. An aerosol of the salt was then generated by injecting $440 \mathrm{ml} / \mathrm{h}$ of the solution through a fluid nozzle into the flue gas close to the burner where the temperature was $1050-1100{ }^{\circ} \mathrm{C}$. A bayonet heat exchanger was inserted into the main duct downstream the formation of the desired aerosol particles to cool down the flue gases. In this way accelerated corrosion caused by the potassium compounds was avoided. The catalyst box contains the plate catalysts was well insulated and heated by an electrical heating wire. The exposure temperature was kept at $350^{\circ} \mathrm{C}$ and the temperature difference over the cross section of the catalyst box at the catalyst inlet was within $4{ }^{\circ} \mathrm{C}$ while the temperature difference between the catalyst inlet and outlet was kept less than $5^{\circ} \mathrm{C}$. A soot blower and a steel grid were installed $20 \mathrm{~cm}$ and $5 \mathrm{~cm}$, respectively, above the catalyst to minimize plugging problems. The soot blower consisted of a steel pipe with a diameter of $16 \mathrm{~mm}$ and a hole of $10 \mathrm{~mm}$, a time controller and connection to compressed air at a pressure of 5 bar. Two additional soot blowers were placed just above the steel grid to blow away the particles deposited on the mesh. Soot blowing was carried out by $3-5 \mathrm{~s}$ of blowing with compressed air at an interval of $30 \mathrm{~min}$. The total flow rate at the outlet of the burner was about $60 \mathrm{~N} \mathrm{~m}^{3} / \mathrm{h}$ and the flow rate through the catalyst was kept at $40-45 \mathrm{~N} \mathrm{~m}^{3} / \mathrm{h}$ by adjusting 
the bypass valve. The experiments were conducted for $1200 \mathrm{~h}$ continuously. After exposure the catalyst plates were removed and immediately tested for SCR activity.

\subsection{SCR activity measurements}

The SCR activity measurements were performed at atmospheric pressure in a fixedbed quartz reactor. The activity was measured on cut out samples of fresh and aerosol exposed catalyst plates $\left(1.7 \times 1.7 \mathrm{~cm}^{2}, 0.25 \mathrm{~g}\right)$ at a total gas flow rate of $3 \mathrm{~L} / \mathrm{min}$. The composition of the feed gas was adjusted to 400 ppm NO, 500 ppm $\mathrm{NH}_{3}, 5 \% \mathrm{O}_{2}, 2.4 \% \mathrm{H}_{2} \mathrm{O}$ and balance $\mathrm{N}_{2}$ by mixing $1 \% \mathrm{NO} / \mathrm{N}_{2}$ ( $\pm 0.1 \%$ abs.), $1 \% \mathrm{NH}_{3} / \mathrm{N}_{2}\left(0.005 \%\right.$ abs.), $\mathrm{O}_{2}(\geq 99.95 \%)$ and balance $\mathrm{N}_{2}(\geq 99.999 \%)$ (Air Liquide) using mass-flow controllers. Activities of the catalysts were measured at $350{ }^{\circ} \mathrm{C}$ after attaining steady state values of temperature and conversion. Steady state conversion values of NO and $\mathrm{NH}_{3}$ gases were measured by an online ABB NDUV gas analyser. The catalytic activity is represented as the first-order rate constant $\left(\mathrm{cm}^{3} / \mathrm{g} \cdot \mathrm{s}\right)$, since the SCR reaction is known to be firstorder with respect to $\mathrm{NO}$ under super stoichiometric $\mathrm{NH}_{3}$ conditions [17]. Assuming plug flow conditions, the first-order rate constants were obtained from the conversion of NO as:

$k=-\left(F_{N O} /\left(m_{c a t} C_{N O}\right)\right) \ln (1-X)$

where $F_{N O}$ denotes the molar feed rate of $\mathrm{NO}(\mathrm{mol} / \mathrm{s}), m_{c a t}$ the catalyst mass $(\mathrm{g}), C_{N O}$ the NO concentration $\left(\mathrm{mol} / \mathrm{cm}^{3}\right)$ in the inlet gas and $X$ the fractional conversion of NO.

\subsection{Characterization}

X-Ray powder diffraction (XRPD) measurements were performed on a Huber G670 powder diffractometer using $\mathrm{CuK}_{\alpha}$ radiation within a $2 \theta$ range of $5-80^{\circ}$ in steps of $0.02^{\circ}$. The BET surface area of the supports and catalysts was determined by nitrogen physisorption measurements on $100 \mathrm{mg}$ samples at liquid nitrogen temperature with a Micromeritics ASAP 2010 instrument. 
The samples were heated to $200{ }^{\circ} \mathrm{C}$ for $1 \mathrm{~h}$ prior to the measurement. For the XRPD and BET measurements the monolith sample was crushed and sieved to get powder without glass fiber.

The adherence on the zeolite plate was determined by immersing the coated monolith samples in acetone and treating it in an ultrasonic bath $(45 \mathrm{kHz}$ and $100 \mathrm{~W})$ for $1 \mathrm{~h}$. The samples were then removed and dried at $110{ }^{\circ} \mathrm{C}$ for $2 \mathrm{~h}$ and weighed before and after the ultrasonic treatment to determine the loss of catalytic coating.

$\mathrm{NH}_{3}$-TPD experiments were conducted on a Micromeritics Autochem-II instrument. In a typical TPD experiment, a sample of about $10 \mathrm{~mm}$ x $15 \mathrm{~mm}$ in size was placed in a quartz tube and pretreated in flowing $\mathrm{He}$ at $500^{\circ} \mathrm{C}$ for $2 \mathrm{~h}$. Then, the temperature was lowered to $100^{\circ} \mathrm{C}$ and the sample was treated with anhydrous $\mathrm{NH}_{3}$ gas (Air Liquide, $5 \% \mathrm{NH}_{3}$ in $\mathrm{He}$ ). After $\mathrm{NH}_{3}$ adsorption, the sample was flushed with $\mathrm{He}(50 \mathrm{ml} / \mathrm{min})$ for $60 \mathrm{~min}$ at $100^{\circ} \mathrm{C}$. Finally, the TPD was carried out by heating the sample from 100 to $600^{\circ} \mathrm{C}\left(10^{\circ} \mathrm{C} / \mathrm{min}\right)$ in He flow $(25 \mathrm{ml} / \mathrm{min})$.

The distribution of potassium in the exposed catalysts was investigated at the Centre for Microstructure and Surface Analysis, Danish Technological Institute by SEM-EDX on a LEO 440 microscope. The samples were prepared using an MT-990 rotary microtome. The samples were kept dry to prevent any dissolution, recrystallization, and removal of potassium compounds. Before analysis, the samples were covered with a very thin carbon film to become conductive. To compare the different spectra and samples, both carbon and oxygen were excluded from the analysis results and the amount of other elements recalculated on a carbon and oxygen free basis.

\section{Results and discussion}

The stability of the suspension used for coating and the adhesion of the coating to the substrate is strongly influenced by the size of the suspended particles in the slurry. It is necessary that the particle size of the zeolite powders is reduced to values smaller than $5 \mu \mathrm{m}$ in order to obtain 
a stable coat $[18,19]$. Initial particle sizes $\left(\mathrm{D}_{50}\right)$ of the HZSM5 and HMOR were found to be 8.3 and $13.7 \mu \mathrm{m}$, respectively. However, the particle size of the original samples was reduced to $<5 \mu \mathrm{m}$ size by milling. The size distribution of the zeolite samples after wet milling is presented in Fig. 2 and the values are reported in Table 1. The average particle size of HZSM5 was $3.6 \mu \mathrm{m}$ and 90\% of the powder particles were smaller than $8.0 \mu \mathrm{m}$. HMOR presented an average particle size of $3.1 \mu \mathrm{m}$ and $90 \%$ was smaller than $17.7 \mu \mathrm{m}$. The particle size distribution of HZSM5 was sharp and symmetric while that of HMOR was broad and asymmetric in shape. Similar particle size distribution patterns were reported by Zamaro et al. for environmental applications of zeolite washcoating honeycomb reactors [20].

The characteristics of the coating depend on various properties of the slurry which in turn depends on the viscosity, $\mathrm{pH}$, solid concentration of the slurry, and the properties of the solid particles [18-20]. Optimum conditions result in better coating which could be checked by minimum loss of weight during the adherence test. Adhesion of the coating is an important parameter to be considered for environmental applications of the catalysts which involve high flows and temperatures as well as soot blowing. Table 1 shows the weight percent of zeolite loss after the ultrasonic test. HZSM5 and HMOR coated plates showed 48 and 37 wt.\% loss. The better adhesion of HMOR could be due to the smaller particle size $\left(D_{50}\right)$ which facilitated strong anchoring on to the substrate. In the present investigation the weight loss was less compared to the reported results without the colloidal silica binder [21]. The colloidal silica has an important effect in enhancing the adhesion of the coating. The small size of the binder particles leading to the filling of the space between the carrier aggregates thus increases the bonding between particles.

In order to deactivate the monolithic catalyst plates, $\mathrm{KCl}$ aerosols are generated by injection of the $\mathrm{KCl}$ solution at the exit of the burner. Characteristics of the aerosols produced in the bench-scale reactor were reported in our previous articles $[13,14]$. Addition of $7.4 \mathrm{~g} / \mathrm{l} \mathrm{KCl}$ solution $(440 \mathrm{ml} / \mathrm{h})$ 
corresponds to a calculated aerosol concentration of $53 \mathrm{mg} /\left(\mathrm{Nm}^{3}\right)$ at $1050^{\circ} \mathrm{C}$. This feed allows continuous operation of the burner and aerosol exposure possible for many hours. The average aerodynamic diameter of $\mathrm{KCl}$ aerosols in the bench-scale reactor was about $0.3 \mu \mathrm{m}$ which is similar to aerosols in the flue gas of Danish straw-fired grate boilers [13].

The XRPD patterns of fresh and $\mathrm{KCl}$ exposed catalysts are shown in Fig. 3. Fresh VWT catalyst showed only support anatase $\mathrm{TiO}_{2}$ patterns indicating that the $\mathrm{V}_{2} \mathrm{O}_{5}$ and $\mathrm{WO}_{3}$ are highly dispersed on the support. Fresh Cu-HZSM5 and Cu-HMOR catalysts showed only support zeolite patterns also indicating that $\mathrm{CuO}$ is highly dispersed in an amorphous state on the surface of the zeolite support. $\mathrm{KCl}$ exposed catalysts had almost similar diffraction patterns and intensity as that of fresh catalysts after $1200 \mathrm{~h}$ of operation at $350{ }^{\circ} \mathrm{C}$, indicating catalysts were thermally stable. The results of the $\mathrm{N}_{2}$-BET surface area measurements are summarized in Table 2 for fresh and $\mathrm{KCl}$ exposed catalysts. The surface area of the fresh VWT, Cu-HZSM5 and Cu-HMOR catalysts was found to be 64,338 and $312 \mathrm{~m}^{2} / \mathrm{g}$, respectively. Surface area of analogous $\mathrm{KCl}$ exposed catalysts was found to be 53,274 and $260 \mathrm{~m}^{2} / \mathrm{g}$. Such a decrease in surface area is due to specific interaction of potassium with the support as well as partial physical blocking of the support pores.

Fig. 4 shows $\mathrm{NH}_{3}$-TPD profiles of fresh and potassium poisoned catalysts in the temperature range $100-600{ }^{\circ} \mathrm{C}$. According to Topsøe et al. [22] chemisorption of $\mathrm{NH}_{3}$ on the Brønsted acid V-OH site is important to activate the ammonia for the SCR reaction. It was also shown that the SCR activity and number of acidic sites are correlated for various catalysts [11, 12, 16]. The results of the $\mathrm{NH}_{3}$-TPD measurements are summarized in Table 2. Fresh catalysts showed high intensity and broad $\mathrm{NH}_{3}$-desorption patterns compared to the corresponding aerosol exposed catalysts. The total acidity of the fresh and poisoned catalysts were: $\mathrm{Cu}-\mathrm{HMOR}>\mathrm{Cu}-\mathrm{HZSM} 5>$ VWT. Cu-HMOR and Cu-HZSM5 catalysts showed high initial acidity and even after $\mathrm{KCl}$ exposure the $\mathrm{Cu}$-zeolite catalysts retained their acidity while the VWT catalyst showed 
comparatively less initial acidity, and lost the majority of the acidic sites after $\mathrm{KCl}$ aerosol exposure.

The SCR activity of fresh and $\mathrm{KCl}$ aerosol exposed $\mathrm{Cu}-\mathrm{HMOR}, \mathrm{Cu}-\mathrm{HZSM} 5$ and VWT plate type catalysts are shown in Fig. 5. Cu-HMOR, Cu-HZSM5 and VWT catalysts showed rate constant values at $350{ }^{\circ} \mathrm{C}$ of $94.3,132.7$ and $47.8 \mathrm{~cm}^{3} /(\mathrm{g} \cdot \mathrm{s})$, respectively. The rate constants observed on these $\mathrm{Cu}$-zeolites are 2-3 times higher than for commercial VWT catalyst. Probably due to the tuneable properties of the zeolite supports such as surface area and $\mathrm{Si} / \mathrm{Al}$ ratio. The $\mathrm{Cu}$ zeolite catalysts also showed enhanced activity compared to a commercial reference in the form of fractionized particles [11]. The observed superior activity of $\mathrm{Cu}$-zeolites in both monolithic and powder forms might indicate that the coating procedure works very well.

Aerosol exposure measurements are more realistic and can give in depth knowledge about the deactivation phenomena. Aerosol exposed $\mathrm{Cu}-\mathrm{HMOR}, \mathrm{Cu}-\mathrm{HZSM} 5$ and VWT catalysts showed rate constant values at $350{ }^{\circ} \mathrm{C}$ of $49.3,56.0$ and $2.3 \mathrm{~cm}^{3} /(\mathrm{g} \cdot \mathrm{s})$, respectively. Hence, the commercial VWT catalyst showed little activity while the $\mathrm{Cu}$-zeolites showed appreciable activity even after $1200 \mathrm{~h}$ of $\mathrm{KCl}$ aerosol exposure. $\mathrm{Cu}-\mathrm{HMOR}$ and $\mathrm{Cu}-\mathrm{HZSM} 5$ catalysts also showed high alkali resistivity in powder form after wet impregnation even at high $\mathrm{K} / \mathrm{Cu}$ ratios of 0.80 and 0.64 , respectively [11].

SEM-EDX analysis was used to investigate the surface structure and distribution of $\mathrm{KCl}$ on the surface and cross section of the plates in order to correlate the deactivation to the $\mathrm{KCl}$ concentration and depth of catalyst penetration. SEM surface images of the $\mathrm{KCl}$ exposed catalysts are shown in Fig. 6. The VWT and Cu-HMOR catalysts exhibited a homogeneous and smooth surface whereas the $\mathrm{Cu}-\mathrm{HZSM} 5$ catalyst showed a more rough surface with fiber glass plate features. The SEM image of the catalysts at high magnification showed homogeneous distribution of $\mathrm{KCl}$ aerosol particles with an average size of around $0.4-0.7 \mu \mathrm{m}$. 
Table 3 shows the results obtained from elemental analysis performed on the catalysts by EDX with the active metal content (wt.\%) and potassium/metal (mole/mole) ratio on the surface and along the wall thickness of the catalyst plate. The average metal content $(\mathrm{Cu}$ or $\mathrm{V})$ is quite close to the theoretical value, as reported in Table 3. At the surface of the catalyst the potassium content was 3.5, 3.0 and 3.8 wt.\% on Cu-HZSM5, Cu-HMOR and VWT catalysts, respectively. At a depth of $300 \mu \mathrm{m}$, the analogous potassium concentration was $0.33,0.29$ and $0.60 \mathrm{wt} . \%$. These results indicate that almost similar concentration of potassium was present on the surface of the catalysts, and that the potassium diffusion rate across the catalyst walls was lower on $\mathrm{Cu}-\mathrm{HZSM} 5$ and $\mathrm{Cu}$ HMOR catalysts compared to the VWT catalyst.

At the surface of the catalyst the K/M ratio was $1.47,1.25$ and 3.14 on $\mathrm{Cu}-\mathrm{HZSM} 5$, $\mathrm{Cu}-\mathrm{HMOR}$ and VWT catalysts, respectively. There was a fast decrease in the potassium/metal ratio from the surface into the catalyst structure. Hence, a depth of $700 \mu \mathrm{m}$ an average potassium/metal ratio of about $0.14,0.12$ and 0.42 was found on $\mathrm{Cu}-\mathrm{HZSM} 5, \mathrm{Cu}-\mathrm{HMOR}$ and VWT catalysts, respectively. This confirms that the potassium is not only deactivating the surface of the catalyst, but also penetrates through the wall of the catalyst causing further deactivation. The penetration mechanism of potassium into the catalyst structure was explained by Zheng et al. [14] to be surface diffusion of the potassium deposited from the finest aerosol particles.

\section{Conclusions}

Deactivation of $\mathrm{Cu}-\mathrm{HMOR}, \mathrm{Cu}-\mathrm{HZSM} 5$ and vanadium SCR catalysts by $\mathrm{KCl}$ aerosols has been investigated. Cu-HMOR and Cu-HZSM5 catalysts are highly active in SCR of NO with $\mathrm{NH}_{3}$ and exhibited high resistance to potassium aerosols. SEM-EDX analysis revealed that potassium was present both on the surface and in the cross section of the catalyst wall. The K/M ratio across the wall of the catalysts was high on the vanadium catalyst $(0.40-0.55)$ while the $\mathrm{Cu}$ - 
zeolite catalysts had significant lower concentrations $(0.20-0.14)$ in the wall. The results of the $\mathrm{NH}_{3}$-TPD experiments showed that a small decrease in total acidity of the $\mathrm{Cu}$-zeolites catalysts was obtained unlike the vanadium catalyst which exhibited a drastic decrease of the acidic sites. The high alkali deactivation resistance is attributed to the high surface area and acidity of the zeolite supports.

\section{Acknowledgements}

Danish Agency for Science Technology and Innovation is thanked for financial support of this work through the Proof-of-Concept (PoC) project 09-076196. Dong Energy A/S and Vattenfall A/S for their financial contribution as well. 


\section{References}

[1] H. Bosch, F. J.J.G. Janssen, Catal. Today 2 (1988) 369.

[2] G. Busca, L. Lietti, G. Ramis, F. Berti, Appl. Catal. B 1 (1998) 18.

[3 P. Forzatti, L. Lietti, Heterog. Chem. Rev. 3 (1996) 33.

[4] S. Brandenberger, O. Kröcher, A. Tissler, R. Althoff, Catal. Rev. 50 (2008) 492.

[5] O. Kröcher, M. Elsener, Appl. Catal. B 75 (2008) 215.

[6] P. Kern, M. Klimczak, T. Heinzelmann, M. Lucas, P. Claus, Appl. Catal. B 95 (2010) 45.

[7] R. Khodayari, C.U.I. Odenbrand, Appl. Catal. B 33 (2001) 277.

[8] Å. Kling, C. Andersson, Å. Myringer, D. Eskilsson, S.G. Järås, Appl. Catal. B 69 (2007) 240.

[9] Y. Zheng, P.A. Jensen, A.D. Jensen, B. Sander, H. Junker, Fuel 86 (2007) 1008.

[10] J.P. Chen, R.T. Yang, J. Catal. 125 (1990) 411.

[11] S.S.R. Putluru, A. Riisager, R. Fehrmann, Appl. Catal. B 101 (2011) 183.

[12] S.S.R. Putluru, S. Mossin, A. Riisager, R. Fehrmann, Catal. Today (In Press).

[13] Y. Zheng, A.D. Jensen, J.E. Johnsson, J.R. Thøgersen, Appl. Catal. B 83 (2008) 186.

[14] Y. Zheng, A.D. Jensen, J.E. Johnsson, Appl. Catal. B 60 (2005) 253.

[15] F. Moradi, J. Brandin, M. Sohrabi, M. Faghihi, M. Sanati, Appl. Catal. B 46 (2003) 65.

[16] S.S.R. Putluru, A. Riisager, R. Fehrmann, Appl. Catal. B 97 (2010) 333.

[17] R.Q. Long, R.T. Yang, J. Catal. 196 (2000) 73.

[18] T.A. Nijhuis, A.E.W. Beers, T. Vergunst, I. Hoek, F. Kapteijn, J.A. Moulijn, Catal. Rev. 43 (2001) 345 .

[19] B. Mitra, D. Kunzru, J. Am. Ceram. Soc. 91 (2008) 64.

[20] J.M. Zamaro, M.A. Ulla, E. Miró, Chem. Eng. J. 106 (2005) 25.

[21] A. Eleta, P. Navarro, L. Costa, M. Montes, Micropor. Mesopor. Mater. 123 (2009) 113.

[22] N.Y. Topsøe, J.A. Dumesic, H. Topsøe, J. Catal. 151 (1995) 241. 


\section{List of tables}

Table 1 Characterization of the support particles and coating stability.

particle size $(\mu \mathrm{m}) \quad$ zeolite loss

$\begin{array}{llllllll}\text { Support } & \mathrm{Si} / \mathrm{Al} & \text { zeolite (wt\%) } & \text { colloidal silica (wt\%) } & \mathrm{D}_{0.1} & \mathrm{D}_{0.5} & \mathrm{D}_{0.9} & \text { (wt.\%) }\end{array}$

\begin{tabular}{llllllll} 
HZSM5 & 15 & 20 & 5 & 1.5 & 3.6 & 8.0 & 48 \\
HMOR & 10 & 20 & 5 & 0.9 & 3.1 & 17.7 & 37 \\
& & & & & & & \\
\hline
\end{tabular}

Table 2 Surface area and $\mathrm{NH}_{3}$-TPD of catalysts.

\begin{tabular}{lcccc}
\hline Catalyst & \multicolumn{2}{c}{ BET Surface Area $\left(\mathrm{m}^{2} / \mathrm{g}\right)$} & \multicolumn{2}{c}{ Acidity $(\mu \mathrm{mol} / \mathrm{g})$} \\
& Fresh & $\mathrm{KCl}$ exposed & Fresh & KCl exposed \\
\hline Cu-HZSM5 & 338 & 274 & 1349 & 1399 \\
$\mathrm{Cu}-\mathrm{HMOR}$ & 312 & 260 & 1590 & 160 \\
VWT & 64 & 53 & 364 & \\
\hline
\end{tabular}

Table 3 EDX analysis on the surface and cross section of the catalysts.

\begin{tabular}{llcccccc}
\hline Catalyst & Metal & \multicolumn{2}{c}{ Potassium content (wt.\%) } & \multicolumn{3}{c}{ Potassium/Metal (mol/mol) } \\
& Content (wt.\%) & Surface & $300 \mu \mathrm{m}$ & $700 \mu \mathrm{m}$ & Surface & $300 \mu \mathrm{m}$ & $700 \mu \mathrm{m}$ \\
\hline Cu-HZSM5 & $4(3.9)^{\mathrm{a}}$ & 3.5 & 0.33 & 0.25 & 1.47 & 0.24 & 0.14 \\
Cu-HMOR & $4(3.8)^{\mathrm{a}}$ & 3.0 & 0.29 & 0.21 & 1.25 & 0.21 & 0.12 \\
VWT & $1.7(1.6)^{\mathrm{a}}$ & 3.8 & 0.60 & 0.45 & 3.14 & 0.55 & 0.42 \\
\hline
\end{tabular}

${ }^{a}$ Metal content measured from EDX analysis on the surface of exposed catalysts. 


\section{Figure captions}

Fig.1 Experimental setup of $\mathrm{KCl}$ aerosol exposure pilot plant.

Fig.2 Particle size distribution of HZSM5 (thick line) and HMOR (dotted line) used for coating suspensions.

Fig.3 XRPD patterns of fresh (thick line) and $\mathrm{KCl}$ aerosol exposed (dotted line) $\mathrm{Cu}-\mathrm{HMOR}, \mathrm{Cu}-$ HZSM5 and VWT catalysts.

Fig.4 $\mathrm{NH}_{3}$-TPD profiles of fresh (thick line) and $\mathrm{KCl}$ aerosol exposed (dotted line) $\mathrm{Cu}-\mathrm{HMOR}, \mathrm{Cu}-$ HZSM5 and VWT catalysts.

Fig.5 SCR activity of fresh and $\mathrm{KCl}$ aerosol exposed $\mathrm{Cu}-\mathrm{HMOR}, \mathrm{Cu}-\mathrm{HZSM} 5$ and VWT catalysts.

Fig.6 SEM surface images of $\mathrm{KCl}$ aerosol exposed $\mathrm{Cu}-\mathrm{HMOR}, \mathrm{Cu}-\mathrm{HZSM} 5$ and VWT catalysts. 

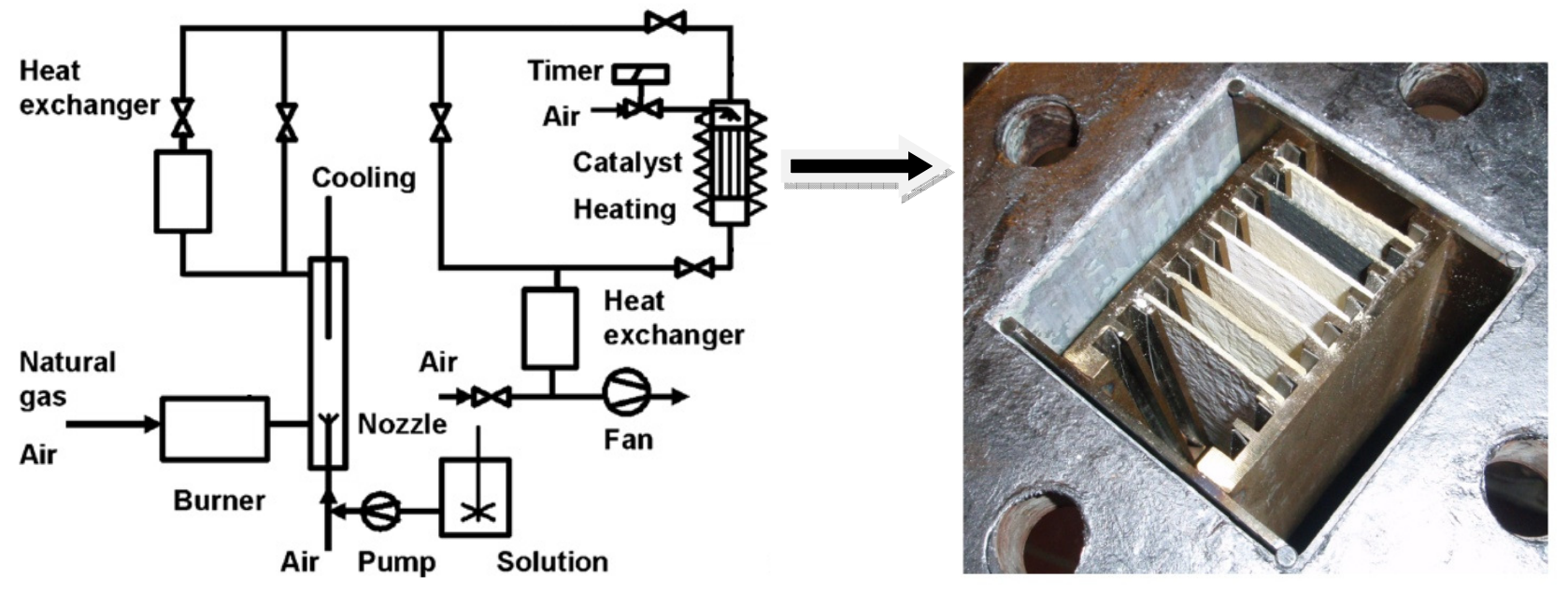

Fig. 1 


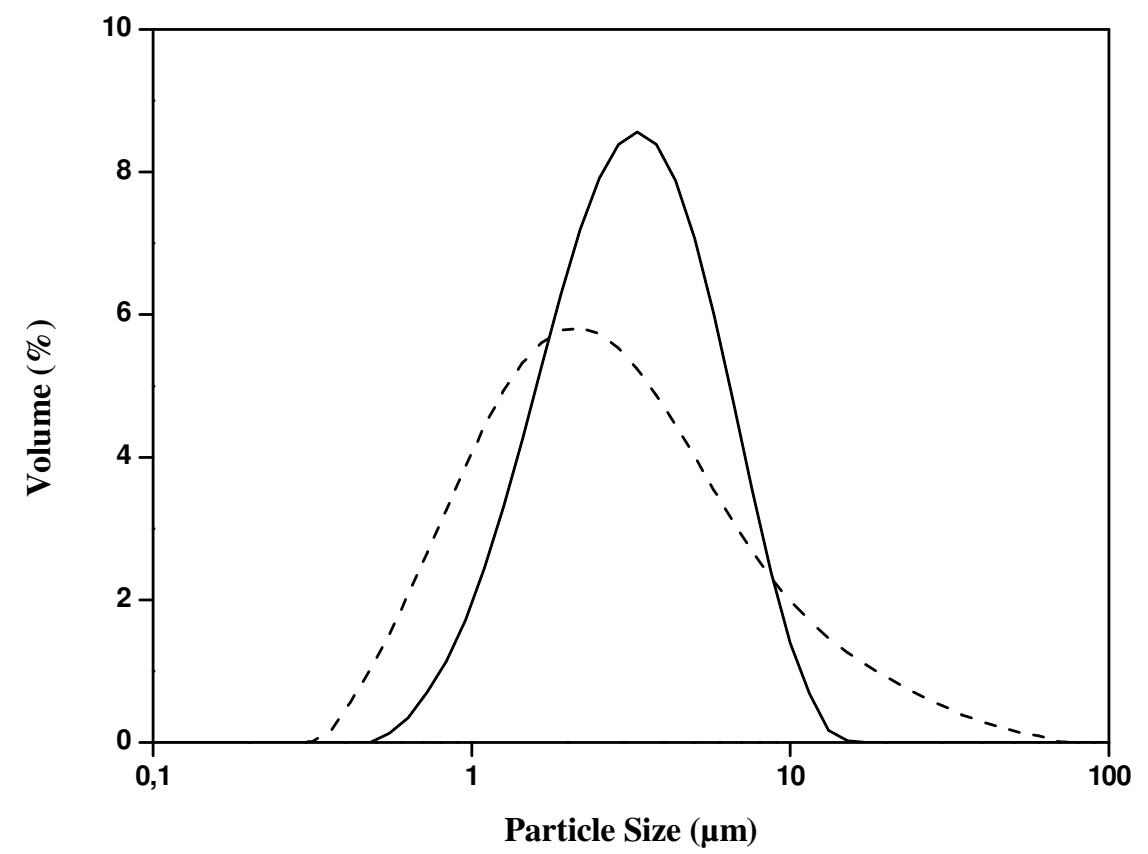

Fig. 2 


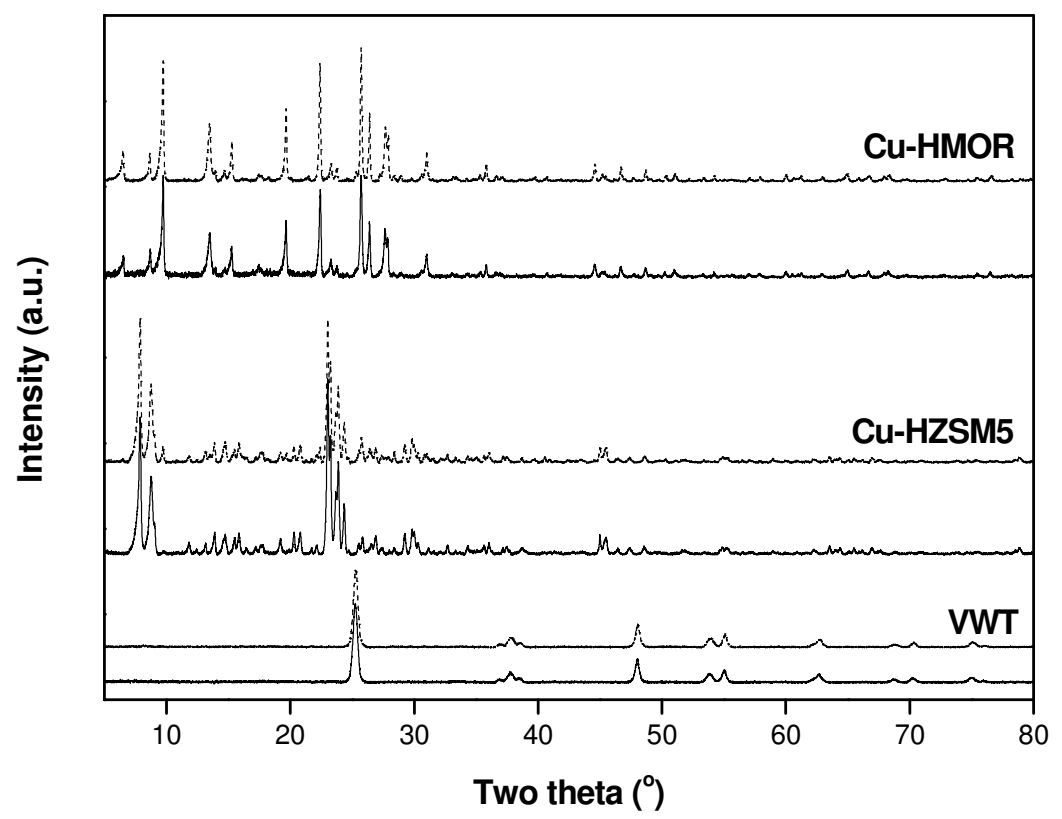

Fig. 3 


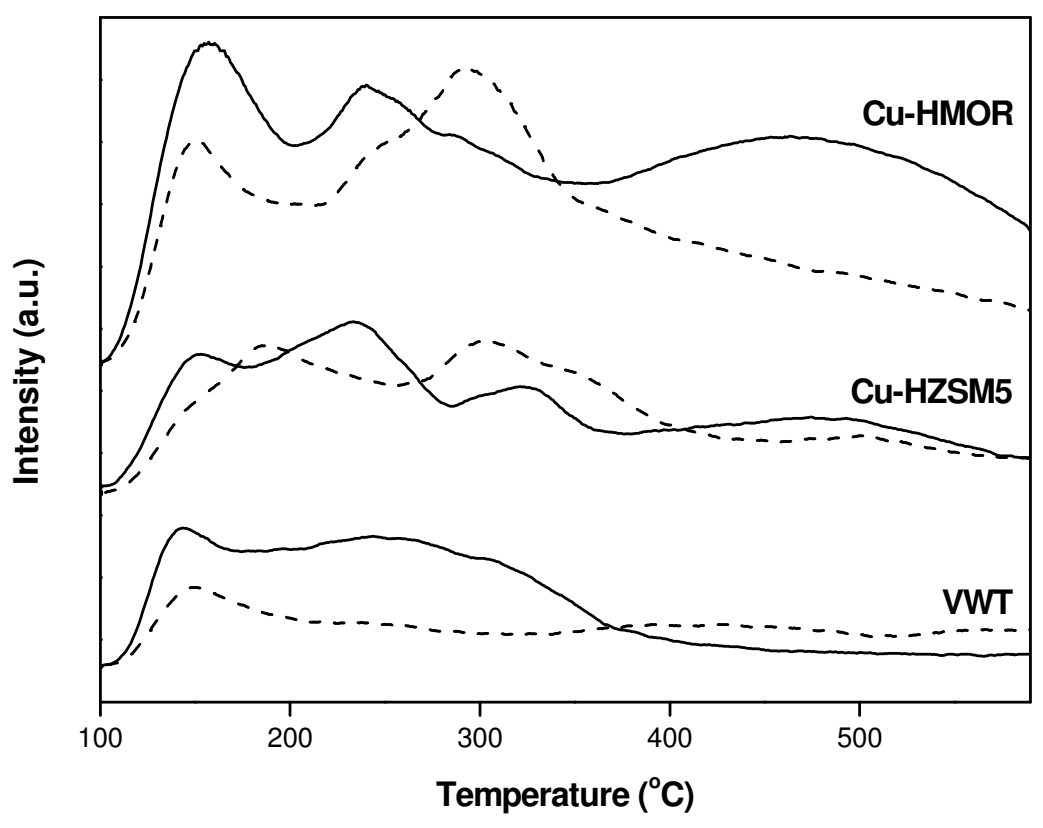

Fig. 4 


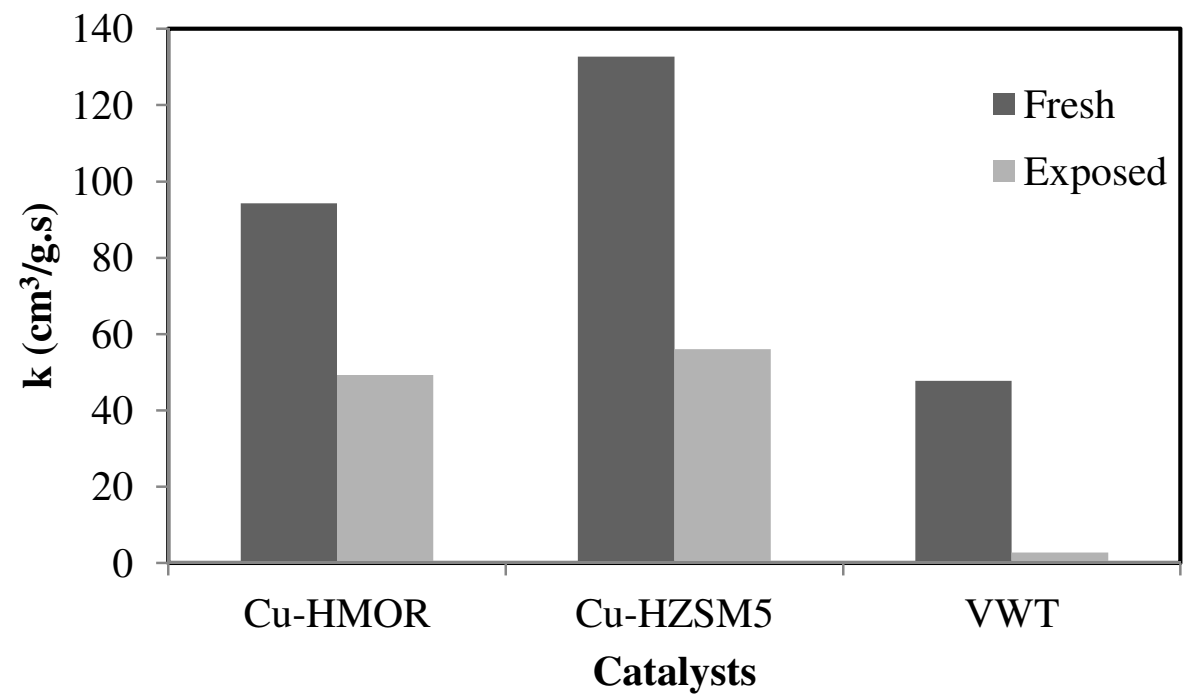

Fig. 5 


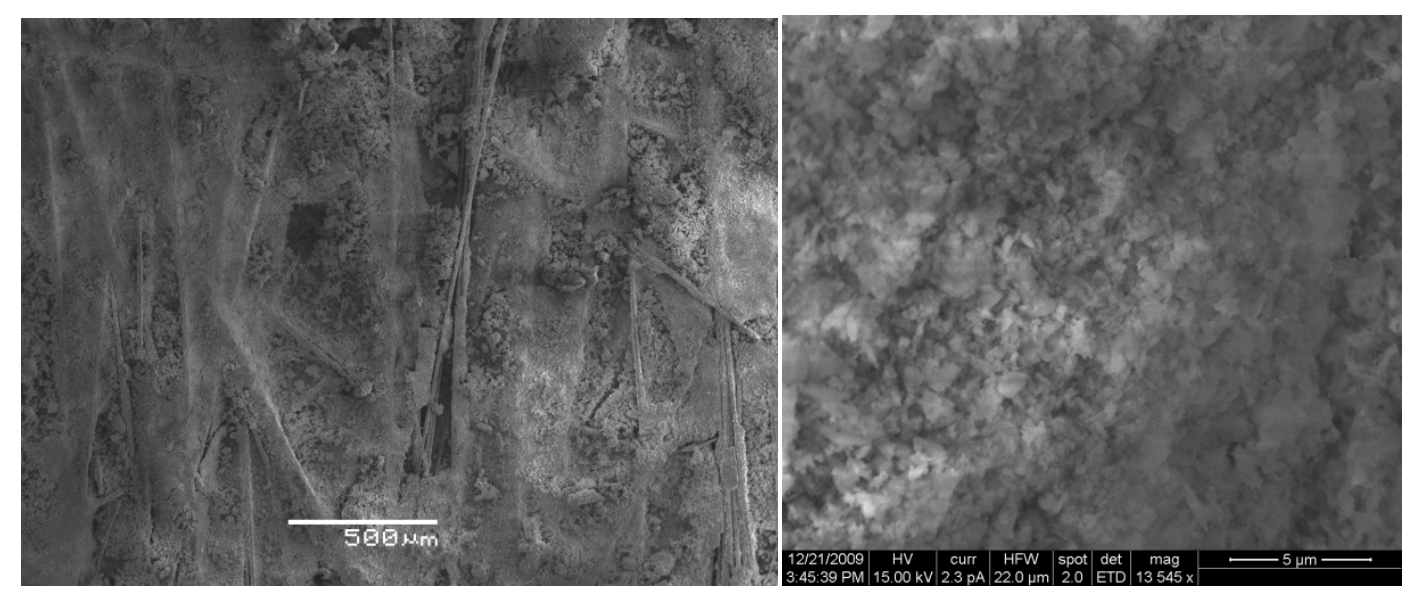

$\mathrm{Cu}-\mathrm{HZSM} 5$

$\mathrm{Cu}-\mathrm{HZSM} 5$
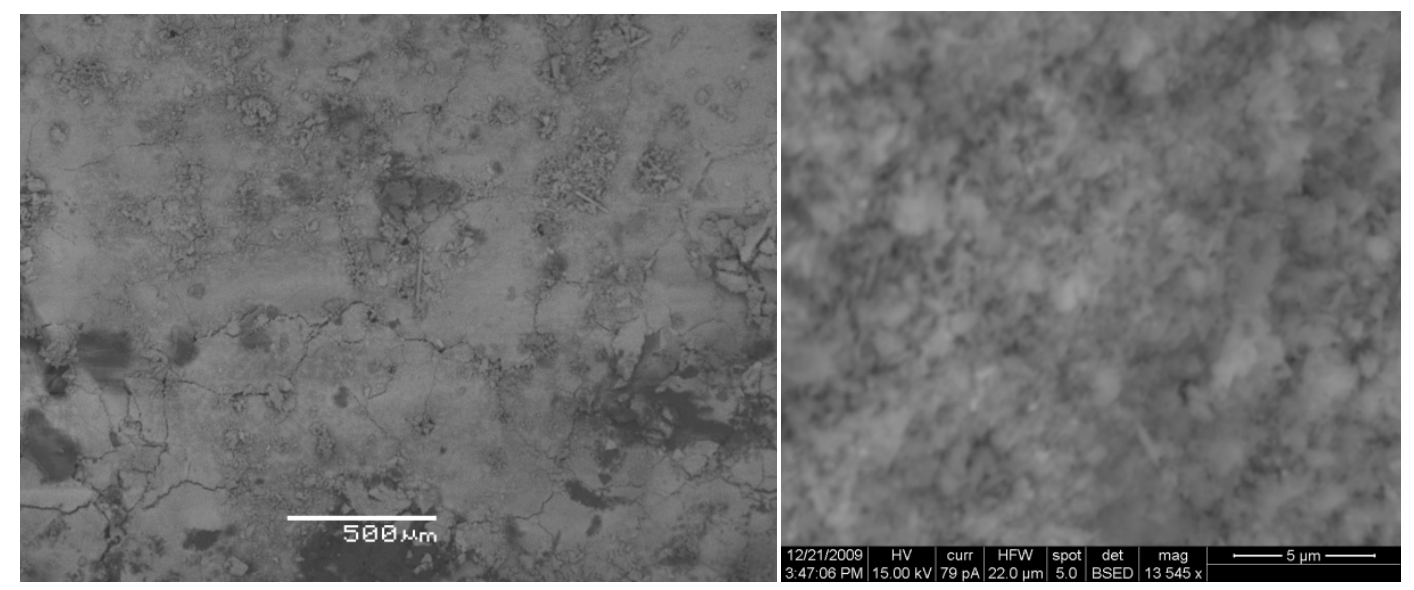

$\mathrm{Cu}-\mathrm{HMOR}$

Cu-HMOR

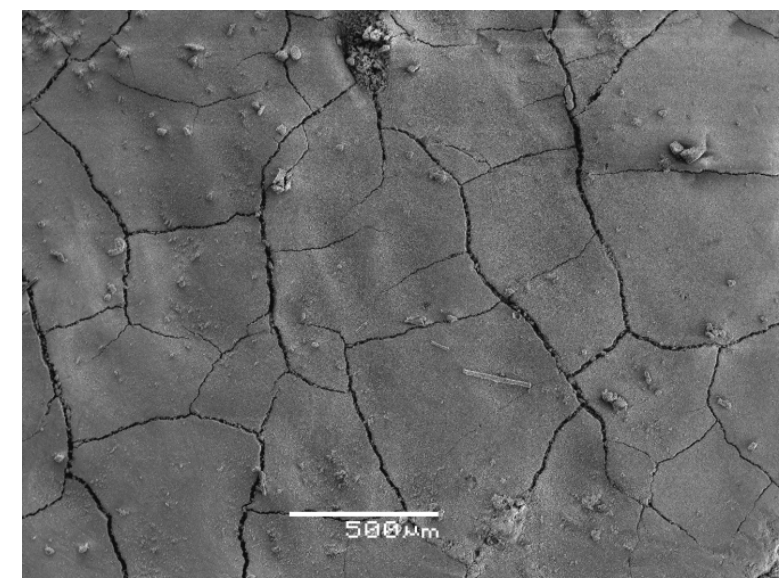

VWT

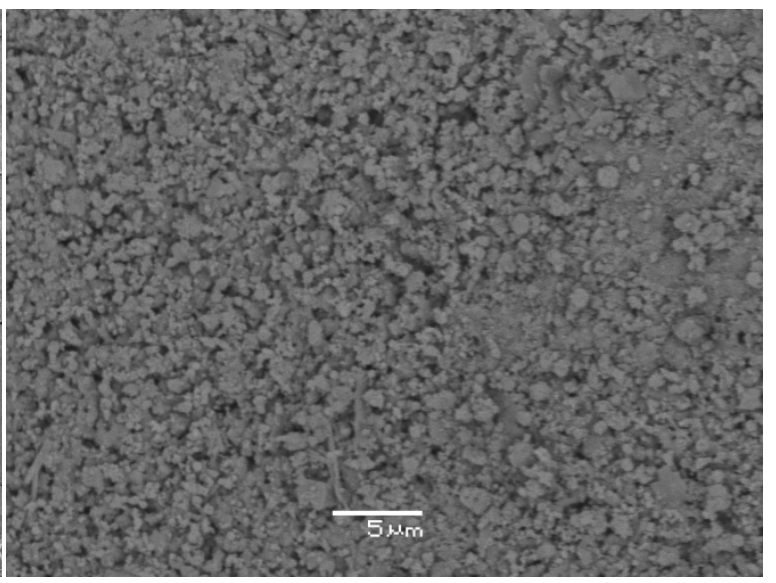

VWT

Fig. 6 